\title{
IS INCREASING INPUT-USE FOR RICE PRODUCTION A PROFITABLE PROPOSITION IN TANZANIA?
}

\author{
Furaha Ndakije RASHID iD
}

\author{
Address: \\ College of Business Education, Department of Business Administration and Marketing, Mbeya, Tanzania. \\ E-mail: rashidfuraha@gmail.com
}

\begin{abstract}
Demand for food staples particularly rice has been increasing tremendously especially in Sub-Saharan Africa relative to supply attributed by a continued rise in population. The shortfall in supply is generally considered to be caused by low use of inputs particularly inorganic fertilizer and improved seed among others. Meanwhile, there is limited empirical evidence to support this notion. This paper aimed at estimating the profitability and yield response to inorganic fertilizer and improved rice seed using cross-section data collected from 256 smallholder rice farmers in Mbarali district Tanzania. Data was analysed using treatment effect model while instrumental variable was used for robustness check. Results shows that inorganic fertilizer use in the study area is not low as generalized by previous studies. It was further revealed that increasing fertilizer and seed use by $1 \mathrm{~kg}$ leads to an increase in yield by $6.2 \mathrm{kgha}^{-1}$ and $_{9.2} \mathrm{kgha}^{-1}$ respectively. Furthermore, rice production is a profitable business though low marginal physical product and high fertilizer price significantly reduce the profitability of fertilizer use. Thus, reducing input costs through well-managed subsidy programs, timely accessibility of inputs coupled with irrigation facilities and good agronomic practices are crucial for sustainable and profitable agricultural development.
\end{abstract}

Keywords: Inorganic fertilizer; seed; profit; rice; Tanzania

JEL: Q12; Q13

\section{INTRODUCTION}

Demand for food particularly staples has been increasing and is projected to further increase in Sub-Saharan Africa (SSA) attributed by a continued rise in population (FAO, 2019). One of the most staple food that is rapidly and widely expanding in terms of production and consumption is rice. Its consumption has tripled from about 9.2 million MT in 1990s to 31.5 million MT in 2018 and it ranks the second largest source of caloric intake, nutrition and food security after maize (USDA, 2018). However, demand for rice has consistently exceeded supply for the last three decades (Tanaka et al., 2013). Currently, only $60 \%$ of rice consumed in SSA is domestically produced (Saito et al., 2019). Inadequate and poor input use particularly inorganic fertilizer and improved seed coupled with poor integrated soil nutrient and water resource management has been cited as major limiting variables for rice production in SSA (Tanaka et al., 2013; Ngailo et al., 2016; Sheahan and Barrett, 2017). The rice yield currently observed in the region is far below the potential yield with a yield gap ranging from $30-90 \%$ (Van Oort et al., 2015; GYGA, 2019).

Tanzania as in other SSA countries is not an exception in terms of low rice yield and low input use. The rice sector in the country is dominated by smallholder farmers (up to 5 ha) who account for about $80 \%$ of food production with annual consumption per capita of $25.4 \mathrm{~kg}$ (URT, 2016; Jayne et al., 2016). The average yield ranges between 1.6 tha ${ }^{-1}$ to 2.4 tha $^{-1}$ which is low relative to the potential yield of 4 to 6 tha $^{-1}$ and 7.5 to 10.8 tha $^{-1}$ for upland and lowland irrigation schemes respectively (Tsujimoto et al., 2019; Ngailo et al., 2016; GYGA, 2019). Low inorganic fertilizer use approximated at $\left(15-22 \mathrm{kgha}^{-1}\right)$ and low productive seed varieties attributed by lack of agronomic knowledge, imperfect input markets and untimely delivery are factors behind this yield gap (Liverpool-Tasie $\boldsymbol{e t}$ al., 2017 and Tanaka et al., 2017).

So far, several efforts have been made by the government of Tanzania in collaboration with development stakeholders to increase the adoption of recommended agronomic practices and technologies including improved seed use, irrigation and fertilizer application through various initiatives including the National Agricultural input voucher scheme in 2008 as an input subsidy program that worth $50 \%$ of input market price, Kilimo Kwanza initiative (2009), Agriculture sector development program I, establishment of the Southern Agricultural growth corridor of Tanzania (2010) and the current agricultural sector development program II launched in 2018 (Tsujimoto et al., 2019; Mligo and Msuya, 2015).

Despite these efforts, rice productivity and input use is still low in Tanzania averaged at 1.6 tonha $^{-1}$ for the period $1961-2017$ albeit of the observed positive trend in rice production shown in Fig. 1. The noted increase in rice production in Tanzania has been fuelled by an increase in cultivated land rather than an increase in productivity. A total area of 330,000 ha has been estimated to be suitable for rice production in Tanzania.

It was also further estimated that $92 \%$ of all rice produced in the country is under upland and lowland rain- 
fed system while only $8 \%$ is under irrigation schemes (Kitilu et al., 2019; Senthilkumar et al., 2018). Low productive rice seeds including Super India, Bwana and Kamalata have been dominant for a number of decades while improved varieties adoption rate has been low due to several factors including lack of agronomic education, high input prices and inaccessibility thereby causing large yield gap (Mligo and Msuya, 2015; Saito et al., 2019).

Table 1 indicates a list of selected local and improved rice varieties that are widely grown in the rain-fed and irrigated schemes in Tanzania based on taste, agroecological system, researcher's yield potential and estimated realized farmers' yield. The continued use of local productive seeds like super India and Wahi pesa is attributed by their aroma. Meanwhile, the adoption of improved seed including TXD 306 is on the rise since they are highly productive.

However, Tsujimoto et al. (2019) argued that, farmers in Sub-Saharan Africa can only adopt and increase input use like fertilizer if they are accessible, affordable and profitable. Therefore, it is worth investigating whether the inorganic fertilizer and seed used in rice production is profit maximizing in the study area to inform policy makers on the allocative efficiency level of the two inputs for agricultural and livelihood development.

Considerable attention by previous studies in Tanzania focused mostly on technical efficiency (Mkanthama et al, 2018) and yield response to fertilizer application but few of them addressed the likelihood of some unobserved characteristics that may affect both fertilizer application and yield leaving allocative efficiency with little consideration (Adedeji et al., 2014; Mhoro et al., 2015). To my knowledge, only one study by Mather et al. (2016) estimated the profitability of inorganic fertilizer use in smallholder maize production in Tanzania and another study by Sheahan et al. (2013) for the case of maize in Kenya. Hence this study sought to address the identified gap particularly for rice in Tanzania. This paper had three objectives (i) To examine rice yield response to improved seed and fertilizer application in the study area (ii) To determine the profitability of rice production in the study area and (iii) To determine the fertilizer and rice seed use allocative Efficiency in the study area by addressing the endogeneity problem that is likely to affect input use decision.

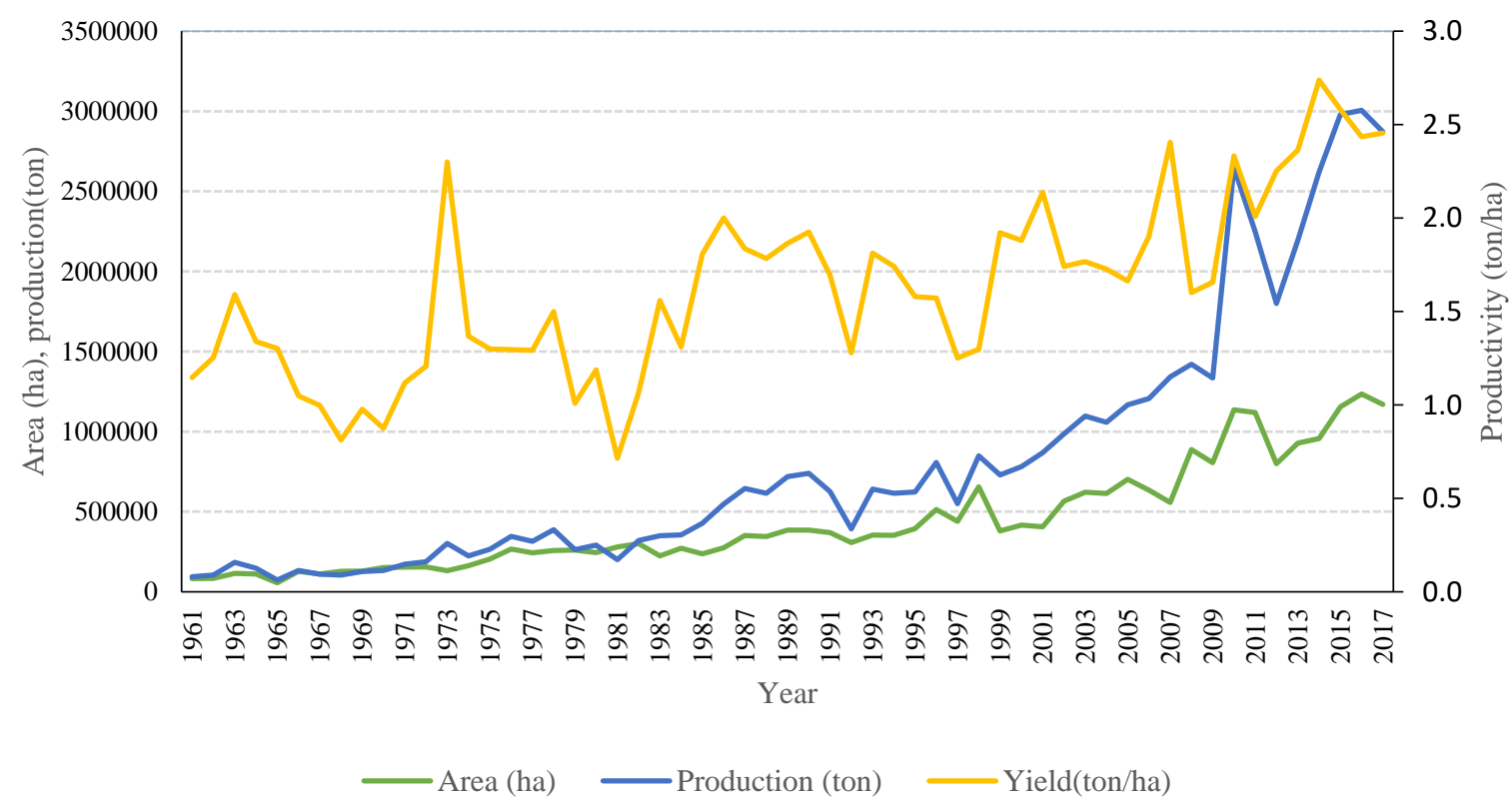

Figure 1: Trends in Rice production, area planted and productivity in Tanzania from 1961 - 2017 Source: FAOSTAT, 2019

Table 1: Rice seed varieties, potential yield, maturity period and agro-ecological system

\begin{tabular}{lllrrr}
\hline Variety & Aroma & $\begin{array}{l}\text { Agro-ecological } \\
\text { system }\end{array}$ & $\begin{array}{c}\text { Days to } \\
\text { maturity }\end{array}$ & $\begin{array}{c}\text { Researcher Potential } \\
\text { yield(t/ha) }\end{array}$ & $\begin{array}{c}\text { Farmer } \\
\text { realized } \\
\text { yield(t/ha) }\end{array}$ \\
\hline TXD306 (2002) & Semi-aromatic & Lowland & $120-125$ & $7.0-8.5$ & $4.5-5.5$ \\
NERICA1 (2009) & Semi-aromatic & Upland & $93-101$ & $3.0-4.5$ & $2.5-3.0$ \\
NERICA2 (2009) & Non-aromatic & Upland & $90-95$ & $3.0-4.0$ & $2.0-3.0$ \\
NERICA4 (2009) & Non-aromatic & Upland & $93-98$ & $4.5-6.0$ & $3.5-4.5$ \\
Komboka (2012) & Semi-aromatic & Lowland & $100-110$ & $5.0-6.5$ & $3.0-4.0$ \\
Super India (1950s) & Aromatic & Lowland & $120-135$ & $2.0-3.0$ & $0.5-1.5$ \\
Wahi pesa & Semi-aromatic & Upland & $110-120$ & xxx & $0.5-1.0$ \\
Tai (2012) & Non-aromatic & Lowland & $100-110$ & $5.5-6.8$ & $3.5-4.5$ \\
\hline
\end{tabular}

Source: KATRIN (2013), xxx data not available. 


\section{Theoretical Framework}

Households' decisions in agriculture are discrete choice made to optimize the use of inputs and output in which a farmer is faced by a constrained utility maximization problem. Farmers have to decide the amount of risky inputs before production begins for each plot level. Inorganic fertilizer, improved seed and water resources are key inputs to increased yield and net revenue (McArthur and McCord, 2017). Input demand is a derived demand which is also a function of input prices and output prices in conjunction with household and farmlevel characteristics (Sigh et al., 1986). Following previous studies (Kouka et al., 1995; Liverpool Tasie et al., 2017; and Sheahan et al., 2013), the yield function used to estimate the input-output relationship in this study is a quadratic production function specified as Eq. (1).

Yield $=\beta_{0}+\beta_{1} X_{1}+\beta_{2} X_{2}+\beta_{3} X_{1} X_{2}+\beta_{4} X_{1}{ }^{2}+$ $\beta_{5} X_{2}^{2}+\delta Z_{i}+\mu$

Where: yield refers to rice output in kilogram per hectare, the $\beta_{s}$ are linear and non-linear parameters that determine the shape of the production function, $X_{1}$ is the quantity of inorganic fertilizer in $\mathrm{kgha}^{-1}$ and $X_{2}$ is the quantity of seed used in rice production in $\mathrm{kgha}^{-1}, Z_{i}$ is a vector of farm level and household characteristics and $\mu$ is the error term of unobserved characteristics.

The quadratic production function is an ideal functional form in agriculture since it is a flexible function that allows both increasing and diminishing returns to production (Kouka et al., 1995). Understanding yield response to fertilizer and seed and input use economics is essential in estimating the relative profitability of input use.

From the economic theory of production, productivity change arises from efficiency in the use of resources. Production efficiency is defined as the performance in transforming available inputs into output given the level of technology (Kehinde et al., 2012). Production efficiency can further be divided into technical efficiencyproduction of maximum output with a given level of input; allocative efficiency -the use of inputs in optimal proportions at least cost of factor prices and given technology while Economic efficiency is the combination of the technical efficiency and allocative efficiency (Salat and Swallow, 2018; Kehinde et al., 2012). Resources are said to be efficiently allocated when the marginal value product of each factor of production is equal to the acquisition price of the factor (Debertin, 2010; Kehinde et al., 2012). Profitability analysis was performed using the gross margin analysis while profitability maximization analysis was evaluated from the estimated quadratic production function. From the production function in Eq. (1), the marginal physical product for seed and fertilizer was estimated from the coefficients of the fertilizer and seed and their interaction terms as in Eq. (2-3).

$\mathrm{MPP}_{f \text { ertilizer }}=\frac{\partial(\text { Yield })}{\partial(\text { Fertilizer })}=F+\beta$ Fertilizer $* X i j(2)$
$M P P_{\text {seed }}=\frac{\partial(\text { Yield })}{\partial(\text { Seed })}=S+\beta$ Seed $* X i j$

Where: MPP is the marginal physical product, $\mathrm{F}$ and $\mathrm{S}$ are the coefficients of fertilizer and seed while the $\beta$ 's are the coefficients of the interaction terms between fertilizer, seed and other farm level characteristics.

The obtained marginal physical product was then used to estimate the marginal value product (MVP) which is the product of the MPP and the output price (Py). The MVP is the value of one unit of output from an additional unit of a variable input. This study also estimated the average physical product (APP) as the ratio of physical output to input used (i.e. APP $=\mathrm{Q} / \mathrm{X}$, where $\mathrm{Q}$ is the output and $\mathrm{X}$ unit of input used). The estimated MPP and APP alongside with the marginal factor cost (MFC) which is the cost of acquiring one unit of input were then used to estimate partial profitability measures namely the Marginal value cost ratio (MVCR) and the average value cost ratio (AVCR) given by Eq. (4) and Eq. (5).

$\operatorname{MVCR}_{x}=\frac{(\mathrm{MPPx} * \mathrm{Py})}{\mathrm{MFC}}$
$\mathrm{AVCR}_{x}=\frac{(\mathrm{APPx} * \mathrm{Py})}{\mathrm{MFC}}$

When the $\operatorname{MVCR}_{x}=1$, implies that profit is maximized from the input use, $\operatorname{MVCR}_{x}>$ 1 implies that inputs are underutilized , $\operatorname{MVCR}_{x}<1$ implies that inputs are used above the optimum. Similarly, the profitability of fertilizer application is measured by the average value cost ratio (AVCR) given in Eq. (5). If an $\mathrm{AVCR}=1$, the farmer breaks even and an AVCR $>1$ implies that fertilizer use is profitable. The AVCR of 2 has been used for profitability studies in Sub-Saharan Africa as a benchmark for an expected increase in profitability derived from mineral fertilizer use by smallholder farmers (Tsujimoto et al., 2019; Liverpool-Tasie et al., 2017).

\section{DATA AND METHODS}

\section{Study Area, Design, Sampling and Data Collection}

This study was conducted in Mbarali District involving irrigated rice farmers in Madibira and Kapunga Schemes on one side and Rain-fed rice farmers in Mbalino village. Mbarali district is among the districts in Mbeya region which is also among the four bread baskets of the country. The district lies in the Usangu basin which is endowed with extensive irrigation schemes suitable for rice production. Agriculture plays a major role in the economy of Mbarali district since it is an activity for more than $80 \%$ of the population. The study used cross-sectional design utilizing data collected from May to June 2018 from a list of farmers participating in the irrigation schemes and a list of farmers from rain-fed scheme. A multistage sampling technique was employed where at first stage the two irrigation schemes and the rain-fed scheme were randomly selected from a list of schemes and rain-fed production schemes in Mbarali. At the second stage, a probability proportionate to sample was used to account for strata representation in the sample. Finally, a total of 256 
respondents constituted a study sample of which 146 respondents were from the irrigation schemes while 110 were from the rain-fed scheme which was then used as a control group. Questionnaire and focus group discussion were used as tools of data collection.

\section{Analytical Methods}

Profitability was measured by using gross margin which is calculated as the difference between total revenue and total variable cost per unit area (ha) and the average value cost ratio described in section 3.1. Gross margin was estimated following NdaNmadu and Marcus (2013) by Eq. (6).

Gross Margin $=\frac{\text { TR-TVC }}{\text { ha }}$.

Where: TR is total revenue and TVC is total variable cost used in production of rice.

One of the challenges involved in estimating the yield response to fertilizer and seed is endogeneity emanated from the decision to use inputs (Liverpool-Tasie et al., 2017). It is also likely that input use can correlate with other farm characteristics. This may affect causal interpretation of the input coefficients. Estimating the production function with OLS would therefore result into biased estimates. To account for the selection bias and endogeneity problem, treatment effect model was employed to estimate the production function while the instrumental variable (IV) was used for robustness check. The treatment effect model contains the regression equation of the outcome and the selection equation constituting the binary endogenous treatment variable that helps in controlling selection bias (Winship and Mare, 1992). The model was estimated by STATA's "etregress" command and maximum likelihood as a default estimator. Following Nguimkeu et al. (2016), the treatment effect model was estimated by Eq. (7) (outcome equation) and Eq. (8) (selection equation).

Yield $_{i}=X_{i}^{\prime} \beta+\mathrm{G}_{i}^{*} \alpha+\mu_{i}$

And the selection equation was modelled as Eq. 8 .

$\mathrm{G}_{i}^{*}=1\left(\mathrm{C}_{i}^{\prime} \theta+\varepsilon_{i} \geq 0\right)$

Where: $X_{i}$ is a vector of exogenous covariates, $\mathrm{G}_{i}^{*}$ is a latent variable for participation in irrigation scheme, $\alpha$ is a scalar that captures the respective treatment effect, $\beta$ and $\theta$ are vectors of size $\mathrm{nx} 1$ and $\mathrm{mx} 1$ respectively, $\mathrm{C}$ is a vector of observed covariates while $\mu_{i}$ and $\varepsilon_{i}$ are error terms.

To account for endogeneity problem, an instrumental variable (IV) following Woodridge (2010) and Bai and NG (2010) was specified using Eq. (9) and the Eq. (10).

Yield $_{i}=X_{1 i}^{\prime} \beta_{1}+\mathrm{X}_{2 i}^{\prime} \beta_{2}+\varepsilon_{i}$

Where: $X_{2 i}$ is endogenous in the view that $\mathrm{E}\left(X_{2 i} \varepsilon_{i}\right) \neq 0$, $X_{1 i}$ is a vector of exogenous variables. The variable $Z_{i}$ in this study cooperative membership was used to instrument $X_{2 i}$ (participation in irrigation scheme) as the Eq. 10 .
$X_{2 i}=\phi^{\prime} Z_{i} \ldots+\mathrm{v}_{i}$

Endogeneity occurs when $E\left(\mathrm{v}_{i} \varepsilon_{i}\right) \neq 0$. For validity of the instrument, $E\left(Z_{i} \varepsilon_{i}\right)=0$.

\section{RESULTS AND DISCUSSION}

\section{Socio-economic Characteristics of the Sampled Rice Farmers}

The descriptive statistics presented in Table 2 indicates that rice production in the study area is largely a smallholder activity with an average farm size of 2 hectares. The typical farmer applies on average 203.92 $\mathrm{kgha}^{-1}$ of inorganic fertilizer and seed rate of $58.43 \mathrm{kgha}^{-1}$. One kilogram of fertilizer and seed used by a farmer costs about 724 and 452 Tanzania shillings respectively. Most farmers $(97.8 \%)$ in the study area use DAP fertilizer as basal fertilizer while UREA is mostly (82.2\%) used as top dressing fertilizer. On average, a rice farmer obtains about $3272 \mathrm{kgha}^{-1}$ of rice produce which is sold at a market price of about 841 per kilogram. The average value cost ratio for both fertilizer and seed used were greater than the benchmark of 2 for Sub -Saharan Africa (Tsujimoto et al., 2019; Mather et al., 2016), implying that rice production in the study area is a profitable business.

However, the use improved seed by rice farmers was minimal which can also be a factor for observed low yield relative to the potential yield of 7.5 to $10.8 \mathrm{kgha}^{-1}$. Similarly, nearly half of the rice farmers' fields in the study area are still faced by moisture stress due to overdependence on rainfall for rice cultivation and less than $50 \%$ of farmers operate their farm activities through producer and marketing cooperative societies. In contrast, a high proportion of farmers used fertilizer in the rice fields. Male household heads dominated rice production in the study area since they are the owner of resources and have more exposure relative to females. A typical household head had an average age of 44 years implying that farmers were still in their productive age $(15-64$ years). Average family size was 5.8 people per household which can be a source of labour if and only if most of the household members are in their productive age, otherwise they can be liability in production process. About $82 \%$ of the respondents had formal education. Education is a critical factor in increasing yield since it enables farmers to make informed decisions regarding both production and marketing of agricultural produce (Ochieng $\boldsymbol{e t}$ al., 2016; Nonvide, 2017).

\section{Gross Margin Estimates}

Based on the gross margin analysis (Table 3), rice production in the study area is a profitable business. A typical rice farmer incurs a total variable cost amounting to $1,028,199$ Tanzania shillings per hectare. The largest share of the cost is on hiring machinery for harvest, cultivation, labour charges and fertilizer purchases. These inputs are the scarcest resources that are subject to competition in the study area. For example, a high number of labourers used are hired from neighbouring districts due to fewer labour force in the study area relative to 
productive land leading to an increase in labour cost through transport and labour management.

The farmer's gross margin was found to be about 1,649,492 Tanzania shillings per hectare. However, to increase the gross margin, the government should subsidize inputs particularly fertilizer and machinery including tractors and combine harvesters so that the cost of harvest can be reduced while promoting further fertilizer use. Cultivation cost is high since an increase in production is due to farm size expansion rather than productivity. This is justified by FAO (2019) food outlook study which pointed out that strong growth in Sub-Saharan Africa is attributed by area expansion.

\section{Production Function Estimates of Yield Response to Fertilizer and Rice Seed Use}

From the production function estimates (Table 4), farm size, the quantity of fertilizer used, household income, market price of fertilizer and access to soil moisture through irrigation were the significant factors that determine variation in the rice yield level in the study area. Rice production was found to exhibit the well-debated inverse farm size-productivity relationship. As the farm size increases by one hectare, rice yield decreased by 292 $\mathrm{kgha}^{-1}$ and the coefficient was significant at $5 \%$. This is consistent with findings from other studies on the inverse farm size productivity relationship (Lipton, 1993; Otsuka, Liu and Yamauchi, 2013; Larson et al., 2014; Carletto, Gourlay and Winters 2015; and Sheng et al., 2019). Small farms are said to be more efficient due to the use of family labour that does not require high supervision compared to large farms that tend to use more capital intensive techniques, more land and hired labour that require more supervision thereby increasing total factor cost (Woodhouse, 2010).

Table 2: Descriptive statistics on social, farm and resource access characteristics

\begin{tabular}{|c|c|c|}
\hline Variable & Mean & Std. Dev \\
\hline \multicolumn{3}{|l|}{ Farm and access characteristics } \\
\hline Farm size (ha) & 2.03 & 1.90 \\
\hline Total quantity of fertilizer $(\mathrm{kg} / \mathrm{ha})$ & 203.92 & 130.08 \\
\hline Quantity of seed $(\mathrm{kg} / \mathrm{ha})$ & 58.43 & 30.99 \\
\hline Price of $1 \mathrm{~kg}$ of seed & 451.72 & 287.50 \\
\hline Price of $1 \mathrm{~kg}$ of fertilizer & 723.47 & 462.97 \\
\hline Land productivity (kg/ha) & 3271.75 & 1741.82 \\
\hline Price of one $\mathrm{kg}$ of rice output & 840.67 & 416.41 \\
\hline Average value cost ratio of seed (AVCR seed) & 101.01 & 88.84 \\
\hline Average value cost ratio of fertilizer (AVCR fertilizer) & 20.27 & 30.35 \\
\hline Access to irrigation facilities $(1=\mathrm{Yes}, 0=\mathrm{No})$ & $58.6 \%$ & \\
\hline Improved seed use $(1=$ Yes, $0=\mathrm{No})$ & $28.5 \%$ & \\
\hline Applied fertilizer in the field $(1=$ Yes, $0=$ No) & $89.1 \%$ & \\
\hline Cooperative membership $(1=$ Yes, $0=$ No $)$ & $45 \%$ & \\
\hline \multicolumn{3}{|l|}{ Household characteristics } \\
\hline Age of the household head (years) & 44 & 11 \\
\hline Family size & 5.8 & 1.89 \\
\hline Sex of household head ( $1=$ male, $0=$ female $)$ & $85.5 \%$ & \\
\hline \multicolumn{3}{|l|}{ Education level of household head } \\
\hline No formal education & $18.3 \%$ & \\
\hline Primary education & $52 \%$ & \\
\hline Secondary education & $22.7 \%$ & \\
\hline Tertiary education & $7 \%$ & \\
\hline
\end{tabular}

Source: Field survey

Table 3: Gross margin Analysis of rice production in the study area

\begin{tabular}{lrr}
\hline Item & \multicolumn{1}{c}{ Tsh/ha } & \% Cost \\
\hline Cost of cultivation & 236799.64 & 23.0 \\
Cost of seed & 26735.61 & 2.6 \\
Total cost of fertilizer & 167087.11 & 16.3 \\
Cost of pesticides + contingencies & 112492.19 & 10.9 \\
Cost of labour & 206769.82 & 20.1 \\
Cost of harvesting & 278315 & 27.1 \\
Total variable cost (Tsh) & $1,028,199.37$ & 100.0 \\
Total Revenue (Tsh) & $2,677,690.82$ & \\
Gross Margin (TR - TVC) & $1,649,491.45$ & \\
\hline
\end{tabular}

Source: Authors Calculations 
However, based on the neoclassical assumptions, farm size -productivity relationship is derived from the farm-size related costs and returns. Given that, the returns obtained from increasing the farm enterprise are larger than the costs the farmer incurs by efficiency loss management, this results into positive farm sizeproductivity relationship. Some studies conducted in Canada, United states of America, Australia and Brazil found results in favour of the neoclassical theory (Sheng and Chancellor, 2019; Deininger and Byerlee, 2012). To date, the findings from various studies are still mixed. For example, the current study by Bevis and Barrett (2019) in Uganda shows that the inverse farm size productivity relationship appears at the plot level rather than farm level and the relationship is more inherent at the periphery of plots relative to the interior due to the agronomic edge effect. The edge effect emanates from increased exposure to sunlight and greater nutrient uptake caused by reduced nutrient competition (Balagawi $\boldsymbol{e t}$ al., 2014). Furthermore, small farms tend to have higher yield due to factor market failure that force smallholders to allocate inputs more intensively (Deininger et al., 2018; Wineman and Jayne, 2017).

Similarly, in this study, quantity of fertilizer applied, household income and reduced moisture stress through irrigation tended to increase rice yield while higher fertilizer price had negative effect on yield. The coefficient of fertilizer use in rice production was positive and strongly significant implying that one-kilogram increase in fertilizer use was associated with an increase in rice yield by about $6.2 \mathrm{~kg} \mathrm{ha}^{-1}$. This result confirms those findings by previous studies that found also a positive significant relationship between fertilizer use and yield (Liverpool Tasie et al., 2017; McArthur and McCord, 2017; Tsujimoto et al., 2019). The use of fertilizer and organic manure is crucial particularly in SubSaharan Africa that exhibits excessive soil nutrient mining caused by increased pressure on productive land.

The positive and squared negative signs in the quantity of fertilizer and seed coefficients implies that initially, when the farmer applied a certain quantity of these inputs, rice yield increased while further increase in the use of these inputs led to the decline in yield. Since increasing and decreasing returns to factors of production is common in agriculture (Debertin, 2012), the quadratic production function employed in this study seems to be appropriate. Furthermore, rice yield increased with an increase in household income. As the household income increased by one Tanzania shilling, rice yield increased marginally by about $1.69 \mathrm{e}^{-4} \mathrm{ha}^{-1}$ ceteris paribus. This could be explained by the household income being invested in farming activities including purchase of improved inputs like fertilizer and seed as well as investing in the use of machinery, technology, more land and search for output markets. This is the case for the rice farmers in the study area where more than $40 \%$ of income earned from rice selling was invested in purchasing inputs for the next production seasons.

Table 4: Treatment effect model estimates of rice Production Function

\begin{tabular}{|c|c|c|c|c|}
\hline \multirow[t]{2}{*}{ Land productivity (kg/ha) } & \multicolumn{2}{|c|}{ Outcome equation } & \multicolumn{2}{|c|}{ Selection equation } \\
\hline & Coefficient & Std. error & Coefficient & Std. error \\
\hline Farm size (ha) & $-292.0^{*}$ & $(129.4)$ & 0.0517 & $(0.104)$ \\
\hline Quantity of fertilizer $(\mathrm{kg} / \mathrm{ha})$ & $6.232^{* * *}$ & $(1.322)$ & & \\
\hline Quantity of fertilizer $(\mathrm{kg} / \mathrm{ha})$ squared & $-0.00680^{* *}$ & $(0.00241)$ & & \\
\hline Seed rate $(\mathrm{kg} / \mathrm{ha})$ & 9.293 & $(8.390)$ & & \\
\hline Seed rate $(\mathrm{kg} / \mathrm{ha})$ squared & -0.0147 & $(0.0327)$ & & \\
\hline Fertilizer(kg/ha)*Seed rate(kg/ha) & 0.00908 & $(0.0124)$ & & \\
\hline Fertilizer(kg/ha) $*$ Farm size (ha) & $-0.338^{*}$ & $(0.187)$ & & \\
\hline Seed rate $(\mathrm{kg} / \mathrm{ha}) *$ Farm size (ha) & -3.112 & $(2.931)$ & & \\
\hline Household income (Tsh) & $1.69 \mathrm{e}^{-4^{* * *}}$ & $\left(1.93 \mathrm{e}^{-5}\right)$ & & \\
\hline Price of $1 \mathrm{~kg}$ of fertilizer (Tsh) & $-0.304^{*}$ & $(0.158)$ & & \\
\hline Land Ownership $(1=$ yes, $0=$ No $)$ & 237.2 & $(323.6)$ & & \\
\hline Age of the household head(years) & 0.452 & $(6.792)$ & -0.00458 & $(0.0128)$ \\
\hline Education level of household head & 35.65 & $(32.02)$ & -0.0346 & $(0.0572)$ \\
\hline Household size & 44.80 & (37.49) & 0.0545 & $(0.0777)$ \\
\hline Access to irrigation $(1=$ Yes, $0=\mathrm{No})$ & $1723.1^{* * *}$ & $(210.5)$ & & \\
\hline Cooperative Member $(1=$ Yes, $0=$ No $)$ & & & $2.889^{* * *}$ & $(0.391)$ \\
\hline Access to Extension $(1=y e s, 0=\mathrm{No})$ & & & 0.024 & $(0.245)$ \\
\hline Sex $(1=$ Male, $0=$ Female $)$ & & & 0.174 & $(0.366)$ \\
\hline Seed $(1=$ Improved, $0=$ local $)$ & & & -0.322 & $(0.247)$ \\
\hline Accessed fertilizer $(1=$ yes, $0=$ No $)$ & & & 0.439 & $(0.345)$ \\
\hline Constant & 402.9 & $(541.6)$ & -1.144 & $(0.739)$ \\
\hline Number of Observations & 245 & & 245 & \\
\hline Wald $\chi^{2}(15)$ & 469.17 & & & \\
\hline Log likelihood & -2103.63 & & & \\
\hline ath (rho) & & & -0.303 & $(0.165)$ \\
\hline LR test of independent equations & & & & \\
\hline$\chi^{2}(1)$ & & & 3.21 & \\
\hline Probability $>\chi^{2}$ & 0.000 & & 0.0733 & \\
\hline
\end{tabular}


Similarly, the effect of access to irrigation facilities by rice farmers on yield was positive and significant. Rice farmers with access to irrigation facilities obtained about 1723 kilograms of rice per hectare more than rain-fed rice farmers. Access to irrigation improves investment in rice enhancing inputs since risks associated with moisture stress leading to output failure is reduced. Thus investing in irrigation schemes is important for yield and agricultural development. This result is consistent with previous studies by Nonvide (2019). In contrast, rice yield decreased with an increase in fertilizer price. A marginal increase in fertilizer price by one Tanzania shillings is linked to a decrease in productivity by about $0.3 \mathrm{kgha}^{-1}$. An increase in fertilizer by smallholder farmers depend on whether the fertilizer is available, accessible, affordable and profitable (Tsujimoto et al., 2019). However, as in Other Sub-Saharan African countries, fertilizer use in Tanzania by smallholder farmers is low as indicated earlier since it is more expensive and inaccessible on timely basis and quantity due to market imperfections and underdeveloped physical infrastructure (McArthur and McCord, 2017).

This study also finds a positive effect of the quantity of improved seed used on rice yield though not significant. The insignificancy of the coefficient of improved seed use might reflect the marginal use of this input in the study area as it was identified in the descriptive statistics that only about $28 \%$ of farmers used improved purchased inputs while the rest used local low productive inputs. Similarly, from the selection equation in Table 4, participation in irrigation schemes was positively and significantly influenced by cooperative membership. Cooperatives provide a platform for social networks where farmers can have access to both input and output markets concurrently with social capital formation (Camara, 2017). The results from the treatment effect model were also confirmed by the use of instrumental variable model in Table 5 where the variables used had the similar signs though there was marginal difference in magnitude. The correlation of the disturbance term between the outcome equation and selection equation ath (rho) in Table 4 is insignificant implying that participating in the irrigation schemes was not subjected to selection bias and hence this validates causal interpretation. For correct identification based on exclusion restriction, an additional variable that influences participation in irrigation schemes but not the outcome variable except through participation was added in estimating results in Table 5. Cooperative membership was used to instrument participation in irrigation since cooperative membership is expected to increase the probability of participation in irrigation schemes due to social networks that enable farmers to make informed decision on production and market dynamics.

The Wu-Hausman test $(\mathrm{p}=0.121)$ indicated that there was no endogeneity problem between participation in irrigation scheme and rice yield. Similarly, the Joint significant first stage $\mathrm{F}$-statistic $(\mathrm{F}=25$. 76) from the Hansen $\mathrm{J}$ test indicate that the chosen instrument is strong and valid since it was greater than all critical values and it is above the normal threshold value of 10 for strong instruments specified by Staiger and Stock (1997). Furthermore, $69.9 \%$ of the variation in the rice yield in the study area is explained by variation in the hypothesized variables.

\section{MPP, APP and Elasticity of Fertilizer and Seed Use}

The marginal physical product was estimated by the margins command in STATA. The results indicate that the marginal physical product for applied fertilizer and improved rice seed in the study area is quite low estimated at about $5.9 \mathrm{~kg}$ and $6.2 \mathrm{~kg}$ respectively. This is similar to the study by McArthur and McCord (2017) conducted in 75 developing countries on fertilizing growth which found that the marginal physical product of applied fertilizer on cereals (rice, wheat, maize, in developing countries for the period 1965 - 2000 was about $7.85 \mathrm{~kg}$ while that of seed was $10 \mathrm{~kg}$. Similarly, a study by Liverpool-Tasie (2015) in Nigeria found also low MPPs for rice that ranged between $8.78 \mathrm{~kg}$ in 2010 and $8.86 \mathrm{~kg}$ in 2012. Based on the MPPs, increasing fertilizer and seed use only is important but not sufficient to increase rice yield since the low yield significantly affect the profitability of both fertilizer and seed use.

The average physical product (APP) are higher than the marginal physical products (MPP) implying that rice farmers in the study area were operating at the economic region of production implying that rice farmers are rational with regard to input allocation. It is a region where farmers get maximum output beyond which output for every additional input diminishes. The elasticities of production are less than a unit and positive confirming also that farmers were operating at the stage II of the production function which is the economic region. It further shows that, one percent increase in the use of inorganic fertilizer and improved seed leads to 0.1 percent and 0.4 percent increase in rice yield ceteris paribus as shown in Table 6.

\section{Profitability of Fertilizer and Seed Use in Rice Production in Mbarali District}

From microeconomic principles, the quantity of fertilizer and seed the farmer will use for profit maximization is determined by the level of input price which is equal to the value of additional quantity of rice produced from those unit of used inputs (fertilizer and seed). Based on the AVCRs, the net benefit of applying fertilizer and improved seed in the rice field was positive and greater than 1 implying that it is profitable to use fertilizer and improved rice seed in the study area. However, Since the MVCRs for both fertilizer and seed are greater than one (MVCR $>1)$, it implies that, rice farmers in the study area could maximize profit by increasing fertilizer and improved seed application rates because the current rates are not profit maximizing. 
Table 5: IV estimates of a Rice yield response to fertilizer and seed application

\begin{tabular}{lrrrr}
\hline Land Productivity (kg/ha) & Coefficient & Standard error & \multicolumn{1}{c}{$\mathrm{Z}$} & $\mathrm{P}>|\mathrm{Z}|$ \\
\hline Farm size (ha) & $-302.8^{*}$ & $(130.3)$ & 6.66 & 0.000 \\
Quantity of fertilizer (kg/ha) & $6.601^{* * *}$ & $(1.328)$ & -2.32 & 0.020 \\
Quantity of fertilizer squared & $-0.00739^{* *}$ & $(0.00243)$ & 4.97 & 0.000 \\
Seed rate (kg/ha) & 6.797 & $(8.639)$ & -3.05 & 0.002 \\
Seed rate (kg/ha) squared & -0.00770 & $(0.0335)$ & 0.79 & 0.431 \\
Fertilizer(kg/ha)*Seed rate(kg/ha) & 0.00764 & $(0.0126)$ & -0.23 & 0.818 \\
Fertilizer(kg/ha) * Farm size (ha) & -0.230 & $(0.197)$ & 0.60 & 0.545 \\
Seed rate (kg/ha)* Farm size (ha) & -2.198 & $(2.976)$ & -1.17 & 0.242 \\
Household income (Tsh) & $0.000148^{* * *}$ & $(0.0000236)$ & -0.74 & 0.460 \\
Price of 1 kg of fertilizer (Tsh) & $-0.333^{*}$ & $(0.163)$ & 6.29 & 0.000 \\
Land Ownership(1=yes, 0 No) & 348.3 & $(333.1)$ & -2.04 & 0.041 \\
Age of the household head(years) & 0.957 & $(6.851)$ & 1.05 & 0.296 \\
Education level of household head & 39.04 & $(32.56)$ & 0.14 & 0.889 \\
Household size (ha) & 40.19 & $(37.89)$ & 1.20 & 0.231 \\
Access to irrigation $(1=Y e s, 0=N o)$ & $1819.7^{* * *}$ & $(273.4)$ & 1.06 & 0.289 \\
Constant & 354.3 & $(550.7)$ & 0.64 & 0.52 \\
Wu-Hausman test & $\mathrm{F}=2.42$ & & & $\mathrm{P}=0.121$ \\
Hansen J test & $\mathrm{F}=25.76$ & & & $\mathrm{P}=0.000$ \\
$\mathrm{R}^{2}$ & 0.6989 & & & \\
Wald $\chi^{2}(15)$ & 537.78 & & & \\
Probability> $\chi^{2}$ & 0.000 & & & \\
Number of Observations & 245 & & &
\end{tabular}

Source: Authors estimations from survey data. ${ }^{*} \mathrm{p}>0.05, * * \mathrm{p}>0.01, * * * \mathrm{p}>0.001, \mathrm{Tsh}=\mathrm{Tan} z a n i a$ shilling

Table 6: MPP, APP, Elasticity and Profitability of fertilizer and seed use

\begin{tabular}{lcccccc}
\hline Yield(kg/ha) & $\mathrm{MPP}_{\mathrm{Xfs}}$ & $\mathrm{APP}_{\mathrm{Xfs}}$ & Elasticity & $\mathrm{MVP}$ & AVCR $_{\mathrm{Xfs}}$ & MVCR $_{\mathrm{Xfs}}$ \\
\hline Fertilizer & 5.9 & 62.4 & 0.095 & 4959.95 & 20.27 & 6.86 \\
Seed & 6.2 & 15.8 & 0.392 & 5203.75 & 101.01 & 11.52 \\
\hline
\end{tabular}

Source: Authors estimations from production function.

\section{CONCLUSION}

This paper aimed at investigating rice yield response to inorganic fertilizer and improved seed and whether the applied input quantities was profit maximizing through the use of quadratic production function. Results indicated that fertilizer rate per hectare, access to irrigation and improved seed had positive effect on rice yield while price of fertilizer and farm size had negative impact on rice yield. For example, increasing fertilizer application rate by $1 \mathrm{~kg}$ would increase rice yield by $6.2 \mathrm{kgha}^{-1}$. Furthermore, the study found that rice farming in the study area is a profitable business though currently, farmers are not maximizing profit due to low use in the level of inputs particularly fertilizer and improved seed. Farmers use low quantities of these inputs since they are expensive, unavailable and due to untimely delivery. The introduction of well-managed subsidy program that is directed towards lowering the cost of inputs particularly fertilizer and improved seed can be one of the remedy to increase fertilizer use among smallholder farmers in the study area and Tanzania in general. However, this should be taken with cautious since excessive and mismanaged subsidy program may result into inefficiency in fertilizer use through overdosing the rates, applying fertilizer in less responsive plots and inefficient application techniques as well as diverting resources for other agricultural and economic sub-sectors into subsidy program leading to their underperformance. Similarly, the government should put more efforts in improving transport infrastructure particularly in rural areas to make inputs accessible and reduce transaction costs as well as encouraging farmers to form producer and marketing cooperatives and development of more efficient irrigation schemes.

\section{Acknowledgements}

The author would like to extend sincere thanks to ASPIRES -Tanzania project for financing this study. Thanks should also go to rice farmers in the study area for their time and crucial information and enumerators including Mr. Ramadhan Ndiyunze on their behalf.

\section{REFERENCES}

ADEDEJI, I. A., AJETOMOBI, J. O., BAMIRO, O. M., IFEGWU, K. U., \& OGUNJOBI, J. O. (2014). Estimating production function with economic content using data envelopment analysis as a complement to marginal analysis in rice production of Kwara State, Nigeria. Asian Journal of Agricultural Extension, Economics and Sociology, $3(3): \quad 189-205 . \quad$ DOI: https://doi.org/10.9734/AJAEES/2014/7742

BAI, J., \& NG, S. (2010). Instrumental variable estimation in a data rich environment. Econometric Theory, 26(6): 1577-1606.

DOI: https://doi:10.1017/S0266466609990727

BALAGAWI, S., JACKSON, K., \& CLARKE, A. R. (2014). Resting sites, edge effects and dispersion of a 
polyphagous B actrocera fruit fly within crops of different architecture. Journal of applied entomology, 138(7): 510518. DOI: https://doi.org/10.1111/jen.12100

BEVIS, L. E., \& BARRETT, C. B. (2019). Close to the edge: High productivity at plot peripheries and the inverse size-productivity relationship. Journal of Development Economics, 102377.

DOI:

https://doi.org/10.1016/j.jdeveco.2019.102377

BYERLEE, D., \& DEININGER, K. (2012). The Rise of Large Farms in Land-Abundant Countries: Do They Have a Future? World Development, 40(4): 701-714. DOI: https://doi.org/10.1016/j.worlddev.2011.04.030

CAMARA, A. (2017). An Analysis of welfare effect of market participation of smallholder farm households in Guinea. Economic Research Guardian, 7(1): 2 - 23.

CARLETTO, C., GOURLAY, S., \& WINTERS, P. (2015). From guesstimates to GPStimates: Land area measurement and implications for agricultural analysis. Journal of African Economies, 24(5): 593-628. DOI: https://doi.org/10.1093/jae/ejv011

DEBERTIN, D. L. (2012). A gricultural production economics. Upper Saddle River, N. J. USA: Pearson Education.

DEININGER, K., JIN, S., LIU, Y., \& SINGH, S. K. (2018). Can Labor-Market Imperfections Explain Changes in the Inverse Farm Size-Productivity Relationship? Longitudinal Evidence from Rural India. Land Economics, 94(2): 239-258. DOI: https://doi.org/10.3368/le.94.2.239

FAO. (2019). Food Outlook - Biannual Report on Global Food Markets. Rome. Licence: CC BY-NC-SA 3.0 IGO. Available at www.fao.org/3/ca4526en.pdf . Accessed on 10/08/2019.

FAOSTAT (2019). Crop area, production and yield by country. $\quad$ http://www.fao.org/faostat/en/\#data/QC. Accessed on 20 September 2019.

GYGA. (2019). Global Yield Gap and Water Productivity Atlas. Available at www.yieldgap.org. Accessed 12 September 2019.

JAYNE, T. S., CHAMBERLIN, J., TRAUB, L., SITKO, N., MUYANGA, M., YEBOAH, F. K., \& KACHULE, R. (2016). Africa's changing farm size distribution patterns: the rise of medium-scale farms. Agricultural Economics, 47(S1), 197-214.

https://doi.org/10.1111/agec.12308

KEHINDE, F. T., OLUKOSI, J. O., ALA, A. L., MAIKASUWA, M. A., \& ODUNSI, A. A. (2012). Determination of the level of resource-use efficiency in Quality Protein Maize (QPM) production in Kaduna State, Nigeria. International Journal of Applied Agriculture and Apiculture Research, 8(1): 24-30.

KATRIN (Kilombero Agricultural Research and Training Institute). (2013). Agricultural Research Bulletin. 28pp.

KITILU, M.J.F., NYOMORA, A.M.S., \& CHARLES, J. (2019). Growth and Yield Performance of Selected Upland and Lowland Rain-fed Rice Varieties Grown in Farmers' and Researchers' Managed Fields at Ifakara, Tanzania. African Journal of Agricultural Research, 14(4): $\quad 197 \quad-\quad 208 . \quad$ DOI: https://doi.org/10.5897/AJAR2018.13611

KOUKA, P. J., JOLLY, C. M., \& HENAO, J. (1995). Agricultural response functions for limited resource farmers in Sub-Saharan Africa. Fertilizer research, 40(2): 135-141. DOI: https://doi.org/10.1007/BF00750098

LARSON, D. F., OTSUKA, K., MATSUMOTO, T., \& KILIC, T. (2014). Should African rural development strategies depend on smallholder farms? An exploration of the inverse productivity hypothesis. Agricultural Economics, 45(3): 355 - 367. DOI: https://doi.org/10.1111/agec.12070

LIPTON, M. (1993). Land reform as commenced business: The evidence against stopping. World Development, 21(4): 641-657. DOI: https://doi.org/10.1016/0305-750X(93)90116-Q

LIVERPOOL-TASIE, L. (2015). Is fertilizer use really sub-optimal in sub-Saharan Africa? The case of rice in Nigeria (No. 1008-2016-80285). International Conference of Agricultural Economists, Milan, Italy. August 8 - 14, 2015.

LIVERPOOL-TASIE, L. S. O., OMONONA, B. T., SANOU, A., \& OGUNLEYE, W. O. (2017). Is increasing inorganic fertilizer use for maize production in SSA a profitable proposition? Evidence from Nigeria. Food policy, 67: 41-51. https://doi.org/10.1016/j.foodpol.2016.09.011

MATHER, D., MINDE, I., WAIZED, B., NDYETABULA, D., \& TEMU, A. (2016). The profitability of inorganic fertilizer use in smallholder maize production in Tanzania: Implications for alternative strategies to improve smallholder maize productivity (No. 1093-2016-88057).

MCARTHUR, J. W., \& MCCORD, G. C. (2017). Fertilizing growth: Agricultural inputs and their effects in economic development. Journal of development economics, 127 : 133-152. https://doi.org/10.1016/j.jdeveco.2017.02.007

MHORO, L., SEMU, E., AMURI, N., MSANYA, B. M., MUNISHI, J. A., \& MALLEY, Z. (2015). Growth and yield responses of rice, wheat and beans to $\mathrm{Zn}$ and $\mathrm{Cu}$ fertilizers in soils of Mbeya region, Tanzania. International Journal of Agricultural Policy and Research, 3(11): $402 \quad$ - $411 . \quad$ DOI: http://dx.doi.org/10.15739/IJAPR.067

MKANTHAMA, J., MAKOMBE, G., KIHORO, J., ATEKA, E. M., \& KANJERE, M. (2018). Technical Efficiency of Rain-fed and Irrigated Rice Production in Tanzania. Irrigation and drainage, 67(2): 233-241. https://doi.org/10.1002/ird.2185

MLIGO, F. E., \& MSUYA, C. P. (2015). Farmer's adoption of recommended rice varieties: A case of Kilombero District of Morogoro Region, Tanzania. South African Journal of Agricultural Extension, 43(1): 41-56.

NDANMADU, J., \& MARCUS, P. L. (2013). Efficiency of ginger production in selected local government areas of Kaduna State, Nigeria. International Journal of Food and Agricultural Economics (IJFAEC), 1(2): 39-52.

NGAILO, J. A., MWAKASENDO, J. A., KISANDU, D. B., \& TIPPE, D. E. (2016). Rice farming in the Southern highlands of Tanzania: Management practices, socioeconomic roles and production constraints. European Journal of Research in Social Sciences, 4(3): 1 - 13

NGUIMKEU, P., DENTEH, A., \& TCHERNIS, R. (2019). On the estimation of treatment effects with endogenous misreporting. Journal of econometrics, 
208(2)

487-506.

https://doi.org/10.1016/j.jeconom.2018.10.005

NONVIDE, G. M. A. (2017). Effect of adoption of irrigation on rice yield in the municipality of Malanville, Benin. African Development Review, 29(S2): 109-120. https://doi.org/10.1111/1467-8268.12266

OCHIENG, J., KNERR, B., OWUOR, G., \& OUMA, E. (2016). Commercialisation of food crops and farm productivity: Evidence from smallholders in Central Africa. Agrekon, 55(4), 458-482. https://doi.org/10.1080/03031853.2016.1243062

OTSUKA, K., LIU, Y., \& YAMAUCHI, F. (2013). Factor endowments, wage growth, and changing food selfsufficiency: Evidence from country-level panel data. American Journal of Agricultural Economics, 95(5): 1252-1258. https://doi.org/10.1093/ajae/aat028

SAITO, K., VANDAMME, E., JOHNSON, J. M., TANAKA, A., SENTHILKUMAR, K., DIENG, I., \& LAMARE, D. (2019). Yield-limiting macronutrients for rice in sub-Saharan Africa. Geoderma, 338: 546-554. https://doi.org/10.1016/j.geoderma.2018.11.036

SALAT, M., \& SWALLOW, B. (2018). Resource Use Efficiency as a Climate Smart Approach: Case of Smallholder Maize Farmers in Nyando, Kenya. Environments, $\quad 5(8)$ : 93. https://doi.org/10.3390/environments5080093

SENTHILKUMAR, K., TESHA, B. J., MGHASE, J., \& RODENBURG, J. (2018). Increasing paddy yields and improving farm management: Results from participatory experiments with good agricultural practices (GAP) in Tanzania. Paddy and Water Environment, 16(4): 749-766. https://doi.org/10.1007/s10333-018-0666-7

SHEAHAN, M., \& BARRETT, C. B. (2017). Ten striking facts about agricultural input use in Sub-Saharan Africa. Food Policy, 67: 12-25. https://doi.org/10.1016/j.foodpol.2016.09.010

SHEAHAN, M., BLACK, R., \& JAYNE, T. S. (2013). Are Kenyan farmers under-utilizing fertilizer? Implications for input intensification strategies and research. Food Policy, 41: 39-52. https://doi.org/10.1016/j.foodpol.2013.04.008

SHENG, Y., \& CHANCELLOR, W. (2019). Exploring the relationship between farm size and productivity: Evidence from the Australian grains industry. Food Policy, 84: 196-204. DOI: https://doi.org/10.1016/j.foodpol.2018.03.012

SHENG, Y., DING, J., \& HUANG, J. (2019). The relationship between farm size and productivity in agriculture: evidence from maize production in Northern China. American Journal of Agricultural Economics, 101(3): 790-806. DOI: https://doi.org/10.1093/ajae/aay104

SINGH, I., SQUIRE, L., \& STRAUSS, J. (1986). Agricultural household models: Extensions, applications, and policy. https://www.google.scholar/. Accessed on 15 September 2019.

STAIGER, D. O., \& STOCK, J. H. (1997). Instrumental variables regression with weak instruments. Econometrica, 65: 557 - 586. DOI: 10.2307/2171753

TANAKA, A., JOHNSON, J. M., SENTHILKUMAR, K., AKAKPO, C., SEGDA, Z., YAMEOGO, L. P., \& BAYUH, B. A. (2017). On-farm rice yield and its association with biophysical factors in sub-Saharan Africa. European journal of agronomy, 85: 1-11. DOI: https://doi.org/10.1080/1343943X.2019.1617638

TANAKA, A., SAITO, K., AZOMA, K., \& KOBAYASHI, K. (2013). Factors affecting variation in farm yields of irrigated lowland rice in southern-central Benin. European journal of agronomy, 44: 46-53. https://doi.org/10.1016/j.eja.2012.08.002

TSUJIMOTO, Y., RAKOTOSON, T., TANAKA, A., \& SAITO, K. (2019). Challenges and opportunities for improving $\mathrm{N}$ use efficiency for rice production in subSaharan Africa. Plant Production Science, 1-15. DOI: https://doi.org/10.1080/1343943X.2019.1617638

URT. United Republic of Tanzania. (2016). Five year development plan 2016/17 - 2020/21: Nurturing Industrialization for Economic Transformation and Human development, Dar es Salaam. Ministry of Finance and Planning. 316pp.

USDA (2018). Production, supply and distribution Online. https://apps.fas.usda.gov/psdonline . Accessed on 25 September 2019.

VAN OORT, P. A. J., SAITO, K., TANAKA, A., AMOVIN-ASSAGBA, E., VAN BUSSEL, L. G. J., VAN WART, J., \& WOPEREIS, M. C. S. (2015). Assessment of rice self-sufficiency in 2025 in eight African countries. Global Food Security, 5: 39-49. DOI: https://doi.org/10.1016/j.gfs.2015.01.002

WINEMAN, A., \& JAYNE, T. S. (2017). Land prices heading skyward? An analysis of farmland values across Tanzania. Applied Economic Perspectives and Policy, 40(2): 187-214. DOI: https://doi.org/10.1093/aepp/ppx038

WINSHIP, C., \& MARE, R. D. (1992). Models for sample selection bias. Annual review of sociology, 18(1): $327-$ 350.

WOODHOUSE, P. (2010). Beyond industrial agriculture? Some questions about farm size, productivity and sustainability. Journal of agrarian change, 10(3): 437453. DOI: $\quad$ https://doi.org/10.1111/j.14710366.2010.00278.x

WOODRIDGE, J. M. (2010). Econometric analysis of cross section and panel data. MIT press. 